CTATTI

ISSN 2519-2523 (print) Chornomors'ka mynuvshyna. -2019. - No.14.

DOI: $10.18524 / 2519-2523.2019 .14 .187077$

УДК (94) 477

\title{
UKRAINIAN SERDIUKS AND OTTOMAN SERDEN-GEÇTIS (towards to discussion about etymology and terms using)
}

\author{
Oleksii Sokyrko \\ ORCID identifier 0000-0003-3841-9782 \\ $\mathrm{Ph} . \mathrm{D}$ (History) \\ Taras Shevchenko National University of Kyiv \\ History Department \\ Volodymyrska Str., 60, Kyiv 01033, Ukraine \\ sag@univ.kiev.ua
}

Serdiuki's infantry regiments were the basis of the hired troops of the rightand left-bank hetmans of the second half - the end of the 17th century, and played an important role in their military and political history in Ruina's period. Among many other issues related to their early history, researchers are still debating the origin of the name "serdiuk". Historiography has suggested that the word comes from the "angry" attitude of the soldiers, or their faithful, "cordial" service to the hetmans, or the name of Colonel Serden'. The context of references to serdiuks in the sources of the 60 - 70's of the 17th c. testifies that formations with this name were distributed both in the army of Hetman Petro Doroshenko and in the Crown troops. Thus, the term itself meant a community of "okhotnyky" (volunteers) from the freelancers of the Right Bank of the Dnieper region who were recruited for hired service. Its etymology is most likely derived from the Turkish word "serden-geçti", which indicated the volunteer formation of the Janissary corps in the Ottoman army. The Serden-geçti were volunteers who participated in especially dangerous military operations for high pay and career promotions. The system of recruitment of these formations ("serdengeçtiler") could serve as a model for the organization of mercenary service in the army of Petro Doroshenko, and hence give them the name "serdiuki".

Key words: serdiuky, hired regiments, Petro Doroshenko, Ottoman Empire, Cossack Hetmanate.

Олексій Сокирко

ORCID identifier 0000-0003-3841-9782 кандидат історичних наук, доцент Київський національний університет ім. Т. Шевченка, історичний факумьтет

вум. Вомодимирська, 60, Київ 01033, Україна sag@univ.kiev.ua

\section{УКРАÏHСЬКI СЕРДЮКИ ТА ОСМАНСЫКI SERDEN-GEÇTI (до дискусії про етимомогію та побутування термінів)}

Сердюиькі піхотні полки були основою найманих війсък право- та лівобережних гетьманів другої половини - кіния XVII cm., ицо відіграли важливу роль в їхній військово-політичній історії. Серед багатьох інших питань, 
пов'язаних із їхньою ранньою історією, дослідниками й зараз дебатується питання походження назви “сердюк”. В історіографії побутували судження, шо слово походить від "сердитої" вдачі вояків, або їх вірної, “сердечної" служби гетьманам, або ж прізвиша полковника Серденя. Аналіз контексту згадок про сердюків у джерелах 60 - 70-х рр. XVII cm. свідчить, ио формування з иією назвою були поширені як в армії гетьмана Петра Дорошенка, так $і$ в коронному війсъку. Отже, сам термін позначав спільноту “охотників" (волонтерів) з війсъкових заробітчан Правобережного Придніпров'я, які вербувалися на найману службу. Його етимологія, швидше за все, походить від туреиького слова "serden-geçti", котрим позначали волонтерсъкі формування яничарсъкого корпусу в османсъкій армії того часу. Serden-geçti були добровольиями, котрі за високу платню та підвищення по службі брали участь у особливо небезпечних воєнних операціях. Система поповнення иих формувань (“serden-geçtiler") в загальних рисах могла послужити взірием для організаиї найманої служби в армї̈ Петра Дорошенка, й відтак дати їм назву “сердюиькоі".

ключові слова: сердюки, наймані полки, Петро Дорошенко, Османсъка імперія, Гетьманшина

Сердюцькі полки - один з найяскравіших феноменів української мімітарної історії доби Гетьманщини, неодмінний атрибут симьної гетьманської вцади, симвоц відваги та мужності. Як відомо, спершу сердюки становими основу найманого війська гетьмана Петра Дорошенка, а після його зречення майже у повному складі перейшли на службу до мівобережних правителів. Сердюцькі, або ж охочепіхотні полки, брали активну участь у війнах із Туреччиною й Кримом в останній чверті XVII ст., були надійною опорою гетьманської вмади всередині країни. Ця, фактично, найбоєздатніша частина армії, була головним опертям гетьмана Івана Мазепи під час його антиросійського виступу. Бімьшість сердюків загинула, мужньо обороняючи Батурин у мистопаді 1708 р., а рештки, котрим вдалося вцікіти, були розпущені указом імператриці Катерини I в 1726 р. [18, с. 100-122].

Серед багатьох недостатньо з'ясованих в історіографії аспектів ранньої історії цих формувань, зокрема, є й проблема походження та історичної етимології їхньої назви - сердюк.

Перші згадки про сердюків відносяться до середини 60-х рр. XVII ст. Зокрема в мисті гетьмана Павла Тетері до вемикого коронного канциера Миколая Пражмовського від 24 червня 1665 р. повідомляється про успішне відбиття “серденятами” й польською залогою Білої Церкви нападів військ Брюховецького [15, с. 238]. Дмитро Дорошенко вважав, що ця назва, котру згодом прибрала наймана піхота Дорошенка, могла походити від прізвища полковника Серденя, який, втім, у цей самий час служив у польському війську й воював проти правобережного гетьмана. На думку Миколи Крикуна, Сердень (Серденя) взагалі $\epsilon$ неісторичною особою, а згадуваний джерелами “Серденів полк" насправді належав до дорошенкового регіменту [15, с. 238-239]. В цьому

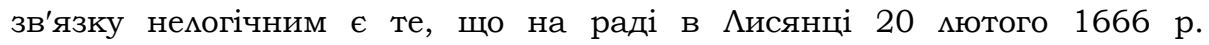
правобережні козаки вимагали виведення обтяжливого й надокучиивого своїми постоями “Серденевого полку” за межі України [7, т. 6, с. 82-88; 
10, с. 65, 69-70]. За версією М.Крикуна, цей епізод начебто був виявом якихось незначних незгод в середовищі Війська Запорозького, що малоймовірно з огляду на гостроту дебатів унаслідок яких "Серденева" старшина викаяла Дорошенка "татарським гетьманом" і навіть покинула раду. Крім того, коли б ішлося про конфмікт саме з сердюками, підписи їхніх командирів навряд чи могли б стояти під текстом інструкції до польського сейму, ухваленій на тій же раді [15, с. 208; 16, с. 291]1.

Швидше за все, ми маємо справу з плутаниною назв у джеремах, спричинену особливостями ділової мови, вживаної козацькими, польськими й московськими канцеляріями, котрі різні за своєю належністю формування - полк Серденя й сердюцькі частини Дорошенка, - однаково іменували "piechota serdeniatów", "серденята", "сердюки". Про те, що сердюки існували одночасно в коронному й гетьманському війську свідчить чимало документів. Так, в цисті примаса Миколая Пражмовського до великого маршалка коронного Яна Собеського 3 березня 1669 р. згадано "kozakow przy nas sie ieszcze wiazancych, Serdyniat nazwanych pospolicie", котрих він радить залишати при польському війську, оплачуючи їхню службу з поборових грошей руських воєводств [1, s. 277]. Ширших відомостей про них ми не маємо, але очевидно, що ці сердюки не входили до компуту коронного війська, перебуваючи на становищі волонтерів, “охотників" котрих уряд затягав додатково на час війни дмя ведення рейдових операцій. Попри намагання Собеського зарахувати серденят до компуту коронного війська й, таким чином поставити на державне фінансування, вони до кінця свого існування продовжували мишатися поза компутом. Навесні 1671 р. при коронному війську мишалося всього 500 піших сердюків, але їхня кількість через несплату жолду неухильно зменшувалася $[1, \mathrm{~s}$. 639640]. У вересні того ж року, допомагаючи комплектувати загони гетьмана Ханенка, Собеський шукав контактів 3 кошовим отаманом Іваном Сірком, через якого збирався “для Ханенка мюдей збирати, а особливо серденят” [1, s. 689, 696]. Отже, серденята мали й якийсь зв’язок із Січчю, можливо, черпаючи там для себе поповнення.

Водночас сердюцькі полки постійно фігурують і у військах

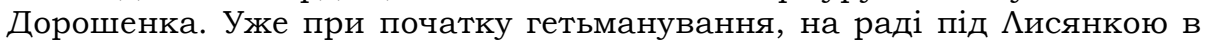
Аютому 1666 р., ми бачимо трьох сердюцьких полковників - Федора Михайленка, Матвія Канівця та Василя Волошина, а також трьох запорозьких (вочевидь, піхотних) - Семена Корсунця, Пилипа Івановича та Івана Чорнобиля [15, с. 223]. Тоді ж Дорошенко сповіщав польського короля про розташування іх над Дніпром і Бугом, "щоб вони були пересторогою від степу й Запоріжжя та щоб знову не вибухла якась ребелія" [10, с. 64]. Ці наймані контингенти, швидше за все були створені ще до обрання Дорошенка на гетьманство, але, не виключено, що за його безпосередньої участі, яко генерального

\footnotetext{
1 Д. Дорошенко витлумачив цю суперечність не як намір ради Аіквідувати наймані полки серденят, а як вимогу вивести з України полк Серденя, що належав до коронного війська й обтяжував населення постоями [10, с. 69-70, 73].
} 
осавула. Так, у мистопаді 1669 р. два сердюцьких полки стояли залогою в Умані [1, s. 462,489]. Наприкінці 1670 р., згідно інформації польського коменданта, серденята брали участь у блокаді білоцерківського замку [1, s. 603]. Козацькі полонені, захоплені в Барі в березні 1671 р., переповідами, що загалом при гетьмані перебуває 5 сердюцьких полків [1, s. 635-636].

Все це дозволяє припустити, що “сердюками” або “серденятами" сучасники іменували спільноту військових заробітчан-“охотників”, які не мали постійного місця осідку, мандруючи на теренах Східного Поділя та правобережної Наддінпрянщини від одного наймача до іншого. Показово, що коли в березні 1669 р. на Корсунській раді постало питання про розпуск сердюцьких полків, котрі в очах рядового козацтва були провідниками самоправної помітики Дорошенка, ïx «приговорики роспустить хто откуды пришел, а приматца за домовые работы, а в войско ходить не велеми" [7, т. 8, с. 145]. Отже, правобережні козаки сприймали серденят, як мюдей прийшлих, до того ж явно не мицарського походження, котрих належало повернути до їх звичних занять (“работы”).

В умовах політичної нестабільності, а надто - постійного дефіциту грошей, серденята періодично опинялися то в козацькому, то в польському таборах. Білоцерківський комендант Ян Аьобель описує серденят, як відважних найманців, які “шукають служби", але їх приймають із великим острахом, бо бояться зради. Деякі з них виявляють готовність служити й Речі Посполитій, однак, пише Аьобель, “треба б їм [за це - O.C.] щось дати й барву пообіцяти” [1, s. 603]. Водночас, серденят цінували за відвагу й вемикий бойовий досвід, набутий на службі у різних володарів. Зауважуючи професіоналізм найманців і прагнучи їхньої мояльності, Ян II Казимир радив коронним регіментарям приваблювати цих “волонтерів і охотників "на свій бік зазивними мистами й щедрим жалуванням, відриваючи в такий спосіб від дорошенкової протекції [1, s. 277]. За правління його наступника Міхала Корибута Вишневецького, відділ сердюків чисельністю в 400-500 чоловік перебував у коронному війську на становищі найманого підроздіку, утримуваного 3 каси великого коронного гетьмана. Королівський двір, витрачаючи досить великі суми на утримання сердюків, надавав цим найманцям аж ніяк не меншого значення, аніж правобережним козакам пропольського Ханенка, котрі так само отримували грошові субсидії [2, s. 290-291]. В “Репартиції» коронного війська 3 1667-1673 рр. серед позаштатних формувань, утримуваних за рахунок екстраординарних сум, значимася сердюцька хоругва Яна Самуеля Мотовила (Motowidło) в кількості 200 ставок (очевидно, близько, 180 жовнірів). Вона мала статус волонтерського підроздіку, на заплату якого було секровано кошти від подимного 1671 р. й 1672 р. допущена до збирання "зимового хліба" (гіберни) [2, s.69].

Етимологія слова "сердюк" не зовсім ясна. "Синопсис" Інокентія Гізеля 1680 р. видання, перераховуючи полки, вислані 1679 р. для відбиття турецької навали під Київ, згадував компанійців і сердюків, зазначаючи, що вони "від доброго свого серця так названі, добрі воїни". 
Явною даниною романтичній традиції кінця XVIII ст. слід вважати виведення назви від суворої, сердитої вдачі сердюків, поданої в “Истории Русов" [12, с. 19].

За бімьш обгрунтованою версією Миколи Костомарова, термін походить від турецького “serdengeçti” (букв. “відчайдух" “шибайголова”) назви волонтерських підроздіків у османській армії, складених з яничарів та сипахів, що виконували особливо небезпечні завдання, отримуючи дуже високу платню й підвищення по службі [5, s. 554-555]. “Серденята - писав Костомаров - есть перевод турецкого слова “серденгести”, что означает “безпощадные" [14, с. 261, прим. 3], посимаючись при цьому на повідомкення мемуарів учасника російсько-турецької війни 1735-1739 рр. пруського офіцера Христофора Германа фон Манштейна (1711-1757). Описуючи сутичку з ханськими військами після переправи через Дністер в серпні 1739 р., Манштейн, зокрема згадує, що російські віддіки були атаковані Імія-Калчак-башею, хотинським комендантом "с 6 т. серденгести или конными янычарами, называемыми безпощадными" [11, с. 158]. Обігруючи турецьку етимологію слова “сердюк”, Костомаров, таким чином, ніби натякав на запозичення цієї назви дмя позначення дорошенкових найманців, коли той прийняв османську протекцію.

Микола Крикун критично поставився до цієї тези, зауваживши, що перші згадки сердюків в Україні джерелами набагато раніші за прийняття Дорошенком османського підданства [15, с. 238]. Це однак, ажніяк не заперечує турецького походження самого слова, котре могло з'явитися у вжитку задовго до Дорошенка. Вплив східних звичаїв і військових практик цілком могічно вписується в соціокультурну модель Козацької України, де суто військовий “орієнталізм” пустив міцні корені ще в попередніх століттях [9, с. 94-172; 17, с. 18-23]. Тож поява османських або татарських запозичень в українському мілітарному мексиконі не конче спричинювалася характером політичних відносин. Тривале військове партнерство між гетьманатом, Портою й Кримським юртом, що розпочалося від середини XVII ст., ще більшою мірою посприяло перемішуванню звичаїв і численним взаємним запозиченням.

Ким, власне, буми "серденгечти" в османській армії? Система serdengeçtiler була особливим типом поповнення емітних частин у постійних військах османської армії (корпусі яничар та сипахів): добровольців, котрі зголосилися до виконання особливо небезпечних бойових завдань в обмін на високу платню й службове підвищення. Як правило, з числа таких волонтерів формувалися ударні загони при штурмах фортець або ж десантні групи в морських операціях, що в силу свого тактичного застосування несли нечувано важкі втрати, котрі могли сягати 80 - 90 \% особового складу. Так, наприклад, в битві при Дарданемлах у мипні 1657 р. десантна партія з 300 яничарських серден-гечтелерів, висаджених на о. Тенедос, втратима майже 250 вояків, а 32000 загону добровольців, що прорвалися до блокованого австрійцями гарнізону Буди в травні 1686 р. вціліло заледве 200. Відчайдухам сплачували майже подвоєну плату за участь у таких ризикованих операціях. Окрім цього, тим, хто вижив гарантувалося переведення до одного 3 шести 
привілейованих полків султанської кінної гвардії (altı bölük halkı): сипагів (sipahiyan), сіляхдарів (silahdaran), улуфеджи (ulufeciyan-1 yemin та ulufeciyan-1 yesar), та гарібів (gurebayan-1 уеmin та gurebayan-1 yesar), що одержували винятково високе забезпечення [13, с. 301]. За зауваженням дослідників, набір серден-гечтелерів, не був формалізованою процедурою, й регулювався звичаєвою традицією, скріпленою усними домовленостями між наймачем і вояком. При цьому відбір охочих здійснювався з основної маси яничарів, що мали середній рівень бойової підготовки й воєнного стажу. В такий спосіб забезпечувався високий рівень взаємної виручки й взаємодії в найнебезпечніших моментах бою [3, p. 163-164].

Втім, принципи добровільного вербунку, матеріальне заохочення, контекст бойового застосування українських сердюків і турецьких серденгестів виглядають цілком тотожними. Таким чином, припущення Костомарова виглядає аргументованим і має цілковиту рацію. При цьому варто зауважити, що турецькі серденгесті були не просто окремими ударними підроздіками яничарського корпусу, а особливою системою набору добровольців для виконання небезпечних задач фактор, котрий так само ріднить ї службу із сердюцькою, що запроваджувала іншу, у порівнянні 3 козаками, мотивацію служби: гроші, трофеї та кар'єрний ріст.

Головним контингентом, який "затягався" на службу до сердюцьких полків, ставали "охотники" - ті, кого Козацька революція, а згодом і Руїна винесли за рамки традиційного станового суспільства, змусивши "живитися" воєнною здобиччю і грабунком. Одну 3 найчисельніших категорій військових заробітчан становили випищики - козаки, що були виписані 3 реєстру, але продовжували брати участь у походах, ідентифікуючи себе 3 рицарським станом. Із часом комусь із них щастило знову посісти місце в козацьких списках, однак іншим, особливо тим, хто не мав землі та постійної осілості, випадав єдиний можливий варіант - кочове вояцьке життя. Із цього середовища напередодні щорічних кампаній формувалися так звані "охотні" полки, до яких збиралися добровольці, "охочі" волонтери, що їх джерела називають "голотою без роду-племені".

Часто "охотники" утворювали окремі від козацьких тимчасові полки, що виникали здебільшого в порубіжних регіонах, швидко зникаючи та відновлюючись (до таких можна віднести кілька подільських полків Звягельський, Аисянський, Могилівський, а також полісько-сіверських Мозирський, Брагинський та Овруцький). Тривале існування судимося тим із них, що контролювали периферійні території, на якій вирували повстанські рухи покозачених селян. Так, у Бузько-Дністровському межиріччі майже до середини $70-\mathrm{x}$ pp. XVII ст. діяли справжні "мікродержави" на чолі з Семеном Височаном, Василем Дроздом та Семеном Кіяшкою-Манжосом, даючи притулок неспокійному «збройному мюду", котрий ходив служити то до Момдавії, то на Запорозьку Січ, то по черзі до право- й мівобережних гетьманів. Аегендарний ватаг подільських "охотників" Семен Кіяшко, спільно із відділами Григорія Дорошенка, брав участь у бойових діях на Аівобережній Україні влітку 
1668 р. разом із московськими військами, але після переходу Поділмя під владу поляків у 1671 р., як і інші полковники, виявив згоду служити Михайлові Ханенку [7, т. 8, с. 109, 150; 10, с. 213]. Щоправда, попри складену присягу й отриману "асекурацію", Кіяшко набрав охотників (його вербувальники дійшли навіть до Чернівців) і вирушив разом із молдавським господарем Григорієм Дукою до Волоського князівства [10, с. 395]. Значна частина складу охотницьких формувань не була прив'язаною до службових грунтів, як звичайне козацтво, та часто взагалі не мала сімей. Здобуваючи "козацького хліба", "охотники" мегко міняли своїх командирів і місце перебування.

Звернімо увагу, що в контексті аналогій із “охотниками"-волонтерами і сердюками, певну подібність за деякими функціями мали також османські gőnűllü - буквально "волонтери, що воюють з серцем", “з охотою”. Ці підрозділи, разом із територіальними ополченнями виставляли й фінансували провінції. Вони належали до провінційних яничарських залог, хоча формально до складу корпусу не входили й не отримували платні, Аише користуючись статусом яничара. В багатьох регіонах гьонюлю компцектувалися з місцевого населення без будь-яких спеціальних критеріїв добору. Головним їх завданням була гарнізонна служба у містах і фортецях [13, с.308]. Подібну формацію, але вербовану вже виключно з різноманітного зброду й декласованих елементів, котрі служили мише за військову здобич, утворювали також akinci (своєрідний аналог польських місовчиків) - головна сима авангардів і розвідки султанської армії [4, s. 249-250; 6, s. 155; 13, с. 306-307].

Так чи інакше, але в українській мові слово “сердюк" могмо з'явитися, як калька з турецької, позначивши функціонально дуже близьку османській традиції групу найманців-волонтерів, що відчайдушно служить своєму суверену за гроші та військову здобич. Поява терміну "сердюк" позначала, очевидно, не тільки виокремлення нової найманської спільноти, але й потребу їі відмежування від інших, аналогічних, найманських ватаг Правобережжя, що існували паралельно. За висловом Марка Блока, “поява слова - це завжди помітний факт, навіть якщо сам предмет вже існував раніше; він відзначає, що настав вирішальний період усвідомлення" [8, с. 91]. Перенесена в Мівобережну Україну разом із втікачами від Дорошенка, традиція іменування найманої піхоти "сердюками" символізувала формування нового військового феномену - найманого піхотного війська національного типу.

\section{Джерема та мітература:}

1.Acta historica res gestas Poloniae illustrantia ab anno 1507 usque 1795. - Kraków, 1880. - Vol.II. - Cz.1.

2.Hundert Z. Między buławą a tronem. Wojsko koronne w walce stronnictwa malkontentów z ugrupowaniem dworskim w latach 1669-1673. - Oświęcim: Napoleon V, 2019.

3.Murphey R. Ottoman Warfare, 1500-1700. - London: UCL Press, 1999.

4. Özcan A. Akinci / /Türkiye Diyanet Vakfi İslâm Ansiklopedisi. - T. 2. - S. 249-250.

5. Özcan A. Serdengeçti / /Türkiye Diyanet Vakfi İslâm Ansiklopedisi. - T. 36. - S. 554-555.

6. Żygulski Z. Sztuka Turecka. - Warszawa, 1988.

7. Акты, относящиеся к истории Южной и Западной России. - СПб., 1873. 
8. Блок М. Апология истриии или ремесло историка. - М., 1973.

9. Грибовский В. Социальная типология казачьих сообществ //Казачество в тюркском и славянском мирах /Институт археологии им. А. Халикова АН РТ. - Казань, 2018. - С.94-172.

10. Дорошенко Д. Гетьман Петро Дорошенко: Огляд його життя і політичної діяльності. -Нью-Йорк: УВАН у США, 1985.

11.Записки Манштейна о России. 1727-1744 /Пер. с французского. - СПб., 1875.

12. История Русов или Малой России. - М.,1846.

13. История Османского государства, общества и цивилизации: В 2 т. /Под ред. Э. Исханоглу. - Москва: Восточная митература, 2006. - Т. 1.

14. Костомаров Н.И. Руина: Гетманства Бруховецкого, Многогрешного и Самойловича / / Костомаров Н.И. Собрание сочинений. Исторические монографии и исследования. - СПб., 1905. - Кн. 6. - Т. XV.

15. Крикун М. Інструкція послам Війська Запорозького на Варшавський сейм 1666 року і відповідь на неї короля Яна Казимира //Крикун М. Між війною і радою. Козацтво правобережної України в другій половині XVII - на початку XVIII століття: Статті і матеріали. - Київ: Критика, 2006. - С. 205-248.

16. Окиншевич $\Lambda$. Центральні установи України-Гетьманщини XVII - XVIII ст. - Київ, 1930. - Ч. 2: Рада старшини.

17. Пилипенко В. Східне обличчя козака Мамая //Вісник Чернігівського національного педагогічного університету. Серія: Історичні науки. - 2015. - Вип. 134. - С. 18-23.

18. Сокирко О. Аицарі другого сорту. Наймане військо Мівобережної Гетьманщини 1669-1726 рр. - Київ: Темпора, 2006.

\section{References:}

1. (1880) Acta historica res gestas Poloniae illustrantia ab anno 1507 usque 1795. Kraków, Vol. II, Cz. 1. [In Polish]

2.Hundert Z. (2019) Między buławą a tronem. Wojsko koronne w walce stronnictwa malkontentów $z$ ugrupowaniem dworskim w latach 1669-1673. Oświęcim: Napoleon V. [In Polish] 3.Murphey R. (1999) Ottoman Warfare, 1500-1700. London: UCL Press. [In English]

4. Özcan A. Akinci In Türkiye Diyanet Vakfi İslâm Ansiklopedisi. T. 2. S. 249-250. [In Turkish] 5. Özcan A. Serdengeçti In Türkiye Diyanet Vakfı İslâm Ansiklopedisi. T. 36. S. 554555. [In Turkish]

6. Żygulski Z. (1988) Sztuka Turecka. Warszawa [In Polish]

7. Akty, otnosyashhyesya k istoryy Yuzhnoj y Zapadnoj Rossyy, SPb., 1873. [In Russian]

8. Blok M. (1973) Apolohyya ystryyy yly remeslo ystoryka, Moskva. [In Russian]

9. Hrybovskyj V. (2018) Socyal"naya typolohyya kazach"yx soobshhestv V Kazachestvo $v$ tyurkskom y slavyanskom myrax: Kollektyvnaya monohrafyya /Ynstytut arxeolohyy ym.A.Xalykova AN RT, Kazan, S. 94-172. [In Russian]

10. Doroshenko D. (1985) Het"man Petro Doroshenko: Ohlyad joho zhyttya i politychnoyi diyal"nosti. - N"yu-Jork: UVAN u SShA [In Ukrainian]

11. (1875) Zapysky Manshtejna o Rossyy. 1727-1744 /Per. s francuzskoho, SPb. [In Russian]

12. (1846) Istoriya Rusov yly Maloj Rossyy, Moskva. [In Russian]

13. (2006) Istoriya Osmanskoho hosudarstva, obshhestva y cyvylyzacyy: V 2 t. /Pod red. E.Iskhanohlu., Moskva: Vostochnaya lyteratura, T. 1. [In Russian]

14. Kostomarov N. (1905) Ruyna: Hetmanstva Bruxoveckoho, Mnohohreshnoho y Samojlovycha V Kostomarov N.Y. Sobranye sochynenyj. Ystorycheskye monohrafyy $y$ yssledovanyya. - SPb., Kn. 6, T. XV. [In Russian]

15. Krykun M. (2006) Instrukciya poslam Vijs"ka Zaporoz"koho na Varshavs"kyj sejm 1666 roku i vidpovid" na neyi korolya Yana Kazymyra V Krykun M. Mizh vijnoyu $i$ radoyu. Kozactvo pravoberezhnoyi Ukrayiny $v$ druhij polovyni XVII - na pochatku XVIII stolittya: Statti i materialy. - Kyiv: Krytyka, S. 205-248. [In Ukrainian]

16. Okynshevych L. (1930) Central"ni ustanovy Ukrayiny-Het"manshhyny XVII XVIII st. - Kyiv, Ch.2: Rada starshyny. [In Ukrainian] 
17. Pylypenko V. (2015) Skhidne oblychchya kozaka Mamaya Visnyk Chernihius"koho nacional"noho pedahohichnoho universytetu. Seriya: Istorychni nauky, vyp. 134, p. 18-23. [In Ukrainian]

18. Sokyrko O. (2006). Lytsari druhoho sortu. Naymane viys'ko Livoberezhnoyi Het'manshchyny 1669 - 1726 rr. - Kyiv: Tempora. [In Ukrainian].

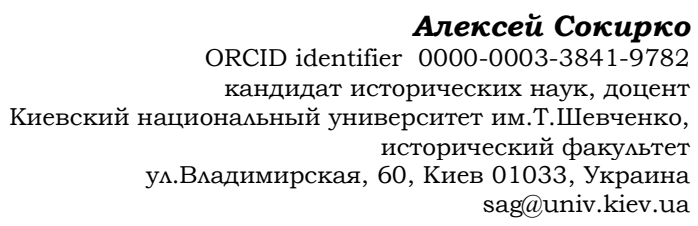

\section{Украинские сердюки и османские serden-geçti (к дискуссии об этимологии и бытовании терминов)}

Сердюцкие пехотные полки были основой наемных войск право- и мевобережных гетманов второй половины - конца XVII в., сыграв важную роль в военно-политической истории периода Руины. Среди многих вопросов, связанных с их ранней историей, исследователями дебатируется вопрос происхождения названия “сердюк". В историографии бытовали мнения, что слово происходит от “сердитого” характера воинов, или их верной, “сердечной”, службы гетманам, или же фамилии полковника Серденя. Анализ контекста упоминаний о сердюках в источниках 60 - 70-х гг. XVII в. свидетельствует, что формирования с этим названием были распространены как в армии гетмана Петра Дорошенко, так и в коронном войске. Сам термин обозначал сообщество “охотников" (волонтеров) Правобережного Приднепровья, которые вербовались на наемную службу. Его этимология, скорее всего, происходит от турецкого слова "serden-geçti", которым обозначали волонтерские формирования янычарского корпуса в османской армии того времени. Serden-geçti были добровольцами, которые за высокую плату и повышение по службе участвовали в особо опасных военных операциях. Система пополнения этих формирований ("serdengeçtiler”) в общих чертах могма послужить образцом для организации наемного службы в армии Петра Дорошенко, и вследствие этого дать им название “сердюцкой”.

Кмючевые слова: сердюки, наемные полки, Петр Дорошенко, Османская империя, Гетманщина.

Отримано: 06.10.2019p. 